UDC 625.8

\title{
Thermodynamic Aspects of Pavement Engineering
}

\author{
B. M. Khroustalev'), Liu Tinguo ${ }^{2)}$, Yu. H. Aliakseyeu ${ }^{1)}$, Li Zhongyu' ${ }^{2)}$, \\ V. D. Akeliev'1), V. T. Minchenya) \\ ${ }^{1)}$ Belarusian National Technical University (Minsk, Republic of Belarus), \\ ${ }^{2)}$ Gaoyuan Company (Henan Province, People's Republic of China)
}

(c) Белорусский национальный технический университет, 2022 Belarusian National Technical University, 2022

\begin{abstract}
Scientific and practical calculations on the thermal stability of typical automobile road surface (semi-limited objects) with fluctuations in air temperatures, transitions from positive to negative, with actual heat transfer coefficients, thermal conductivity of components, specific mass isobaric heat capacities, material densities, periods of regular fluctuations are presented. The study shows that temperature fluctuations occur in road surfaces, therefore deformations are brought about in them, generating thermal cracks. Thermal deformations include free, proportional to temperature gradients, stressed deformations due to temperature stresses, characterized by linear thermal expansion coefficients. In road materials, physical and mechanical properties change over time: strength, moduli of elastic longitudinal deformations, shear, transverse deformation coefficients. Thus, the temperature of pavement materials depends on the coordinates, time, and thermophysical characteristics of the materials. Thermal engineering calculations have shown that many road surfaces have limited thermal stability; under the influence of relatively small external influences, they are more stable (supercooled water vapor exists for a short time, turning into a liquid, saturated, supersaturated steam into a superheated liquid, this depends on the radiation characteristics of the surfaces, the presence of external disturbances, etc.). Thus, a complex non-stationary thermal regime takes place, when the temperature fields of the coatings, their gradients of temperature potentials, and masses depend on the boundary conditions of the $1^{\text {st }}-4^{\text {th }}$ kind. A citation analysis of the data of the Journal Citation Reports of world scientific serial publications has been developed to carry out research on heat and mass transfer in road surface. The analysis shows that in order to improve the reliability and durability of pavements, fundamental studies of both the physical and technical and thermal properties of all components of road construction mixtures are of great importance.
\end{abstract}

Keywords: road surface, pavement, structure, heat- and mass transfer, coatings, heat exchange, characteristics, model, coefficient, condition, research

For citation: Khroustalev B. M., Liu Tinguo, Aliakseyeu Yu. H., Li Zhongyu, Akeliev V. D., Minchenya V. T. (2022) Thermodynamic Aspects of Pavement Engineering. Science and Technique. 21 (1), 28-35. https://doi.org/10.21122/2227-10312022-21-1-28-35

\section{Теплотермодинамические аспекты дорожных одежд}

\author{
Акад. НАН Беларуси, докт. техн. наук, проф. Б. М. Хрусталев ${ }^{1)}$, \\ Лю Тингуо ${ }^{2)}$, канд. техн. наук, доц. Ю. Г. Алексеев ${ }^{1)}$, Ли Чжунъюй' ${ }^{2}$, \\ докт. техн. наук, проф. В. Д. Акельев ${ }^{1)}$, канд. техн. наук, проф. В. Т. Минченя ${ }^{1)}$ \\ ${ }^{1)}$ Белорусский национальный технический университет (Минск, Республика Беларусь),
${ }^{2)}$ Компания «Гаоюань» (провинция Хэнань, Китайская Народная Республика)
}

Реферат. Представлены научно-практические расчеты теплоустойчивости типовых автомобильных дорожных покрытий (полуограниченные объекты) при колебаниях температур воздуха (переходы от положительных к отрицательным значениям), приводятся реальные коэффициенты теплоотдачи, теплопроводность компонентов, удельные массовые изобарные теплоемкости, плотности материалов, периоды регулярных колебаний. Исследования показывают, что в дорожных покрытиях имеют место флуктуации температур, поэтому в них возникают деформации, генерирующие

\section{Адрес для переписки}

Хрусталев Борис Михайлович

Белорусский национальный технический университет

просп. Независимости, 65,

220013, г. Минск, Республика Беларусь

Тел.: +375 17 293-93-52

tgv_fes@bntu.by

\author{
Address for correspondence \\ Khroustalev Boris M. \\ Belarusian National Technical University \\ 65, Nezavisimosty Ave., \\ 220013, Minsk, Republic of Belarus \\ Tel.: +375 17 293-93-52 \\ tgv_fes@bntu.by
}


температурные трещины. Температурные деформации включают свободные, пропорциональные градиентам температур напряженные деформации, обусловленные температурными напряжениями, характеризуемые коэффициентами линейных температурных расширений. С течением времени в дорожных материалах изменяются их физико-механические свойства: прочность, модули упругих продольных деформаций, сдвига, коэффициенты поперечной деформации. Таким образом, температура дорожных покрытий зависит от координат, времени и теплофизических характеристик материалов. Теплотехнические расчеты показали, что многие дорожные покрытия имеют ограниченную теплоустойчивость; под влиянием сравнительно малых внешних воздействий более устойчивы (переохлажденный водяной пар через короткое время превращается в жидкость, а насыщенный, перенасыщенный пар - в перегретую жидкость, это зависит от радиационных характеристик поверхностей, наличия внешних возмущений и т. д.). То есть имеет место сложный нестационарный тепловой режим, когда температурные поля покрытий, их градиенты потенциалов температур, массы зависят от граничных условий 1-4-го рода. Разработан цитат-анализ с применением данных Journal Citation Reports отбора мировых научных серийных изданий для выполнения исследований по тепло- и массопереносу в дорожных покрытиях. Анализ показывает, что для повышения надежности и долговечности дорожных одежд важны фундаментальные исследования как физикотехнических, так и теплофизических свойств всех компонентов дорожно-строительных смесей.

Ключевые слова: дорожная одежда, структура, тепло- и массоперенос, покрытия, теплообмен, характеристики, модель, коэффициент, состояние, исследование

Для цитирования: Теплотермодинамические аспекты дорожных одежд / Б. М. Хрусталев [и др.] // Наука и техника. 2022. Т. 21, № 1. С. 28-35. https://doi.org/10.21122/2227-1031-2022-21-1-28-35

\section{Introduction}

Roads at different temperatures constitute open nonlinear heterogeneous thermodynamic systems. All types of their deformations should be viewed through the lens of synergetics referring to the methodology of general scientific level focusing the surface material components structuring at critical temperatures. The specific dissipative structures resulted from these processes are adapted to ambient conditions for the reason that due to heat and mass transfer the road pavement has a complex structure formed under the dissipation of energy and mass [1-4].

Such a pavement structure can be provided considering the Benard effect when convection occurs in a viscous liquid layer at a certain difference in surface temperatures with the hexagonal cells formation due to molecular motion or intensity jump in heat transfer. In this case, with an increase in the temperature difference, the rate of convective heat transfer increases. With decreasing temperature, the pavement dissipates part of the accumulated heat into the environment, and temperature stresses change. Different deformations occur when the stress of the ultimate strength of the road components are identical; removal of a part of the heat accumulated in the road covering due to free surface deformation acquires an abrupt nature. For example, a decrease in air temperature by $30{ }^{\circ} \mathrm{C}$ leads to a change to $0.45-0.50 \mathrm{~m}$ in the road temperature pattern [5].

The ambiguous nature of heat and mass transfer processes during road construction and service creates the prerequisite for the multicomponent secondary resources technology with the effective recycling of used materials containing assessment of their properties, heat and mass transfer processes, their physical and technical indicators for specific mixtures. At the same time, the durability, thermal and physical specification, energy efficiency of road pavement depend on validity of their physical and mathematical models.

\section{Pavement models and structures}

Start with, it is necessary to determine the area of research on methods of generalizing information on mass and heat transfer; factual materials and much more besides. The quantity of the patented road materials and the possibilities of experimental research can be brought into compliance by increasing the quality of experimental work or by optimizing the calculations [6-10].

Analysis of the mechanisms of heat and mass transfer processes in road objects should facilitate the relocation of research on engineering the materials with contemplated properties from the laboratory into a multidimensional mathematical inquiry model. Multidisciplinary specialists should initiate modern pavement concept depending on the required material pattern.

The calculation of thermophysical characteristics of ingredients, mixtures, composite materials is usually performed applying analytical dependencies and correlation obtained because of physical models and experimental data approximations upon which they are accepted. Physical models of pavements can be considered corpuscular, continuous, corpuscular-continuous, etc.

Corpuscular models characterize physical properties of systems depending on their structure, forces of interaction between its molecules, atoms and the nature of their thermal motion. Continuous 
models represent the road pavement and its single components as a continuous medium. Then, based on the study of various transfer processes, the dependences of the effective coefficients of transfer from the structure of their ingredients and concentration are determined $[7,11]$.

Corpuscular-continuum models consider the road pavement as a solid body; the molecular theory allows calculating the physical properties of a substance with its other known physical properties. Combined methods focus on mixed models applying a phenomenological approach to the calculation of generalized conductivity. They have proved to be effective in the methods of molecular physics that closely reflect the transport processes in many systems, and enabling analytical determination of coefficients of generalized conductivity of heterogeneous thermodynamic system.

In addition, the structure with closed inclusions contains a binder in which components that are not in contact with each other are distributed. A specific feature of this structure is the continuity of binder components in different directions and their discrete arrangement. Obviously, the components are geometrically unequal in a structure with inclusions. Granular and bonded materials from monolithic particles are considered as systems between structures with inclusions and interpenetrating components. Since the contacting elements, pores have a continuous range of solid ingredients, voids, therefore, there are no breaks in the contact zones of the particles, and the contact surface is much smaller than the crosssectional area of the components. During heat and mass transfer of granular materials, the area of their contact changes and can be transformed into a system with interpenetrating components.

In some cases, it is advisable to classify road pavement by the structure nature, the number of ingredients, their aggregate state, physical and chemical processes of component interaction and consider them as mechanical and non-mechanical. Mixtures are mechanical where the coefficients of generalized conductivity of the initial ingredients do not depend on their concentration and are not typical heterogeneous systems.

There is no gainsaying that a clear boundary between heterogeneous and homogeneous systems not always occurs. The secondary research based on the works by G. N. Dulnev, Yu. P. Zarichnyak, R. Collins, A. V. Lykov and others shows the spontaneous processes in road pavement evolve towards equilibrium state $[1-5,7,11,12]$. It is worth noting that roads located under various climatic conditions and consideration should be given to the following physical and mechanical types of moisture bonding in the capillary-porous spaces of road and other objects held in undefined proportions (Tab. 1) [4].

In road structures, depending on the construction technology, climatological factors, their operation, schemes of various models of road material elements (for example, combined structures with interpenetrating components and inclusions, structures with interpenetrating components, with inclusions of various shapes: spherical, cubic, etc.) can be represented as follows (Fig. 1) [1, 5, 11].

Types of moisture bonding in road surface materials [12]

\begin{tabular}{|c|c|c|c|}
\hline Structural bonding & Bonding in microcapillaries & Bonding in macrocapillaries & Hydration bonding \\
\hline Gel formation & $\begin{array}{l}\text { Water absorption from the air } \\
\text { upon direct contact }\end{array}$ & $\begin{array}{l}\text { Water absorption upon direct } \\
\text { contact in through capillaries } \\
\text { and from the air in closed } \\
\text { through capillaries }\end{array}$ & $\begin{array}{l}\text { Water adhesion upon direct } \\
\text { contact with the road surface }\end{array}$ \\
\hline $\begin{array}{l}\text { Water is captured during } \\
\text { the gel structure formation }\end{array}$ & $\begin{array}{l}\text { Capillary pressure due to the } \\
\text { liquid surface curvature }\end{array}$ & The same & $\begin{array}{l}\text { Surface tension characterized } \\
\text { by a contact angle } \Theta \text { to } 90^{\circ}\end{array}$ \\
\hline $\begin{array}{l}\text { Gelatinous bodies ( } 1 \% \text { solids + } \\
+99 \% \text { water })\end{array}$ & $\begin{array}{l}\text { Coating with capillaries } r \text { up to } \\
10^{-5} \mathrm{~cm}\end{array}$ & $\begin{array}{l}\text { Coating with capillaries } r \text { more } \\
\text { than } 10^{-5} \mathrm{~cm}\end{array}$ & $\begin{array}{l}\text { Non-porous hydrated } \\
\text { (hydrophilic) surfaces }\end{array}$ \\
\hline $\begin{array}{l}\text { Mechanical water retention, } \\
\text { monomolecular layer } \\
\text { adsorptively bound }\end{array}$ & \multicolumn{2}{|c|}{ Mechanical bonding of water (side layer adsorptively bound) } & $\begin{array}{l}\text { Mechanical water retention } \\
\text { (surface moisture layer } \\
\text { adsorptively bound) }\end{array}$ \\
\hline $\begin{array}{l}\text { Evaporation, moisture squeezing } \\
\text { by pressure, structural failure }\end{array}$ & \multicolumn{2}{|c|}{ Higher pressure than capillary, evaporation } & $\begin{array}{l}\text { Mechanical methods, } \\
\text { evaporation }\end{array}$ \\
\hline $\begin{array}{l}\text { The body changes its properties, } \\
\text { a quasi-solid body is formed. } \\
\text { Water immobilizes in the structure } \\
\text { and changes its properties }\end{array}$ & \multicolumn{3}{|c|}{$\begin{array}{l}\text { The bulk of the absorbed water is free and retains its properties. The body retains its basic } \\
\text { properties changing some of them due to the adsorbed water formation }\end{array}$} \\
\hline
\end{tabular}



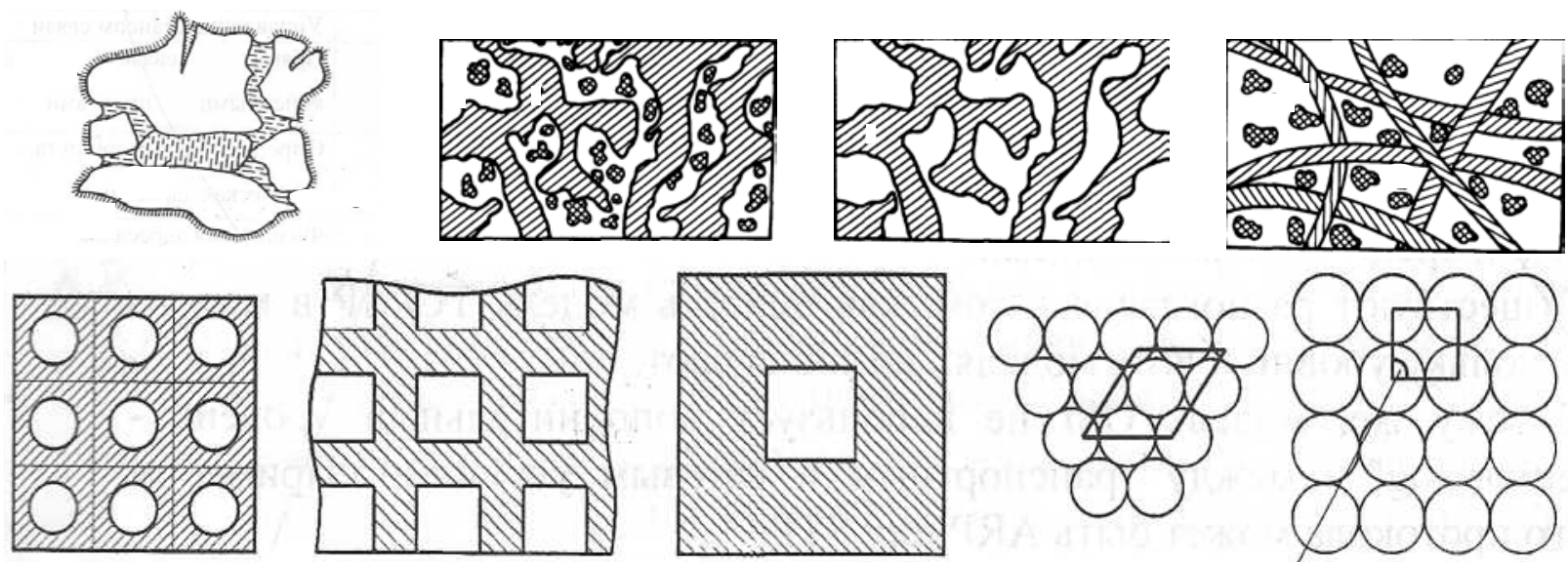

Fig. 1. Structural schemes and models of mixtures in road surface materials

\section{Thermodynamic stability of road pavement}

The studies have shown that low external influences contribute to the transition from the labile state of the road platform structure to the stable one. States of relatively stable equilibrium (metastable) are those states when the road surfaces keep in for a long time, and low external influences that cause changes in the thermophysical parameters of the road do not lead to a transition to other states. In other cases, the road platform should be considered in a metastable state persisting intermediate, relatively stable and labile [13].

If the system does not exchange heat, mass, mechanical work with the ambient environment the specific internal energy and specific volume are usually constant for it. Since the entropy of an isolated system tends to a maximum, therefore, it is maximum in an equilibrium isolated road system $(d s=0), T d s \geq d u+p d v$, i. e. $d s \geq 0$ for irreversible processes in isolated systems. The $>$ sign corresponds to an unstable equilibrium of road surface.

If $s=s_{\max }$ then $d s=0 ; d^{2} s<0$ arguing the entropy to be maximum in equilibrium. When the road pavement interacts with the environment, the equilibrium conditions change and depend on the intensity of the interaction of the "road platform - ambient environment” system.

The following conditions for mass thermophysical interactions (junctions) of the road platform (with air, upper atmosphere) are known:

a) the heat exchange occurs in the "road platform - ambient environment" system at constant values of pressure and entropy;

b) the specific volumes of the road platform components are constant, the heat exchange with the environment is stationary $(d v=0, d s=0)$; c) if $d u \leq T d s-p d v$ then $u=u_{\min }, d u=0$, $d^{2} u>0$

d) as $s=$ const, $\quad p=$ const $(d p=0, \quad d s=0)$ since $h=u+p v, d h=d u+p d v+v d p$, therefore, $d h \leq T d s+v d p$ and consequently the criterion of road platform equilibrium is $h=h_{\min }, d h=0$, $d^{2} h>0$.

Significant factors affecting the calculation accuracy when the probability of transition from one state to another increases (vapor - water, ice - water, etc.), in addition, some substances in the solid state have several phases. For example, water is in a liquid state in temperatures of $0-100{ }^{\circ} \mathrm{C}$ and under atmospheric pressure, it turns into ice at $0{ }^{\circ} \mathrm{C}$ and under atmospheric pressure, and it turns into a vapor state at a temperature above $100{ }^{\circ} \mathrm{C}$. When the pressure changes, the temperature changes at the points of phase transitions: from the liquid phase to the gaseous and vapor phases, here the heat is spent on expansion work and overcoming the intermolecular interaction forces and destroys the associated complexes with a decrease in the substance density [13].

During melting and sublimation the heat of phase change is spent on the crystalline failure of the elements. Change from solid to gaseous phase usually occurs at low pressures (the so-called sublimation); the reverse process is desublimation where the phase densities change sharply: melting and vaporization.

Therefore, the conclusion is in the disunity of research in the mathematical modeling of the calculation of thermal and moisture processes in real road objects. In this regard, based on the calculation profile the goal is to establish and develop effective experimental studies of restored, erected, 
and modernized road objects with the most comprehensive consideration of the specifics of impact on them of thermodynamic mass transfer factors, design solutions and other features [6, 7].

To achieve this, the following tasks were considered:

- to develop physical and mathematical models of the processes in various road pavement bases on the known solutions of the internal heat and mass transfer under various boundary conditions as close as possible to real ones;

- on the basis of the obtained solutions, the development of engineering calculation methods for the optimal thermophysical design of single and multi-layer roads as well as substantiated methods of field studies of road objects for heat and mass permeability were implemented.

The scientific novelty of the project is the presentation of combined methods for calculating heat and mass transfer processes in multilayer road pavement with various thermal, physical and mechanical specifications, boundary and initial conditions. At present, there are data of calculating the thickness of hydroaerodynamic and thermal boundary layers under boundary conditions of the $1^{\text {st }}-3^{\text {rd }}$ types [2-4]. At the same time, it was assumed that the road durability during the operation period is a mix of preventive road maintenance, measures for the road traffic engineering and safety when its transport with operational condition and safety are ensured taking into account the rainfall intensity, constructive, heat and mass transfer specifications of covering.

In this case, the mathematical problem statement should include a correction of differential equations of heat and mass conductivity, radiationconvective factors describing the process of heat transfer through the layers of pavement, initial conditions, temperature field in them and on the surface at the initial time point, boundary conditions, internal and external problems. Internal problems are related to real thermodynamic processes, heat and mass transfer in various systems of road pavement with justified coefficients of thermal conductivity, vapor and mass permeability, filtration and under boundary conditions of the $1^{\text {st }}-4^{\text {th }}$ types. The external are related to the specific handling a problems of heat and mass transfer from interfacing cement-concrete surfaces of road pavement (sand, soil, concrete, etc.), heat and mass conductivity potentials, coefficients of heat assimilation, potential, heat, and thermal diffusivity, etc. In this case, the decisive function is of the temperature fields at stationary and nonstationary heat mass flow, in thermal, dynamic boundary layers characterized by sharp temperature fluctuations, their gradients of heat assimilation, heat and mass stability, isotherms of sorption - desorption.

Road pavement in various climatic regions can be represented as flat, single- and multi-layered, with curved surfaces where the temperature differs from the temperature of the "incident" (contacting) liquid: droplet, vapor, gaseous, etc., at flow rates depended on coordinates, aero-, hydro- and gasrheological parameters (Fig. 2) [2]. Obvious manageable (correlated), uncontrollable factors depend on multifactorial efficiency determined by capital investments, construction duration, economic and environmental sustainability, minimum accident rate (people, transport, etc.), construction technology, operation, development of design and computer comprehensive proposals (justification), practical solutions.

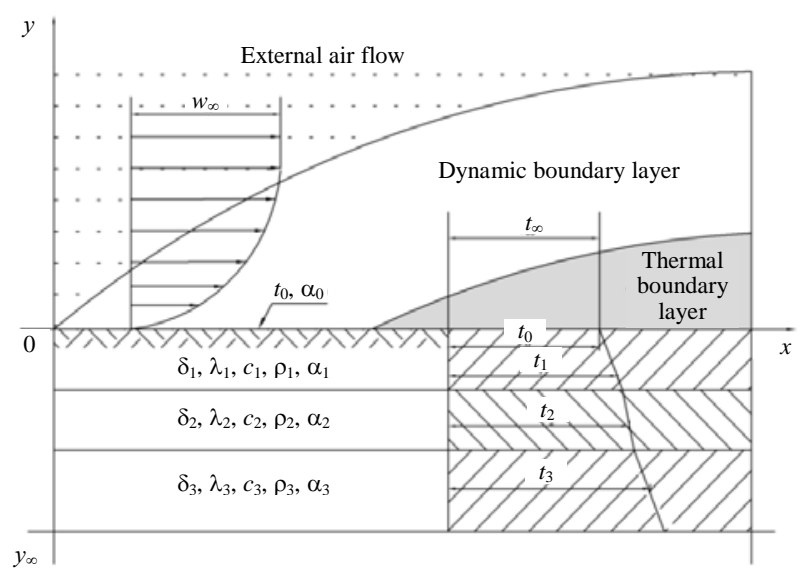

Fig. 2. Diagrams of dynamic and thermal boundary layers on a partially heated cement-sand road pavement (heated areas are shaded)

Differential and integral curves of material pore size distribution were obtained for various types of concrete hardening. Structural specifications of cement-sand and other materials of external enclosing structures are presented using X-ray microanalyzers. Diagrams of the dynamic and thermal boundary layers at various sections of the cementsand road pavement as well as stereo images of the surface fracture, filtration flow dependence on pressure drops at various moisture content and material density are shown in Fig. 3, 4. 

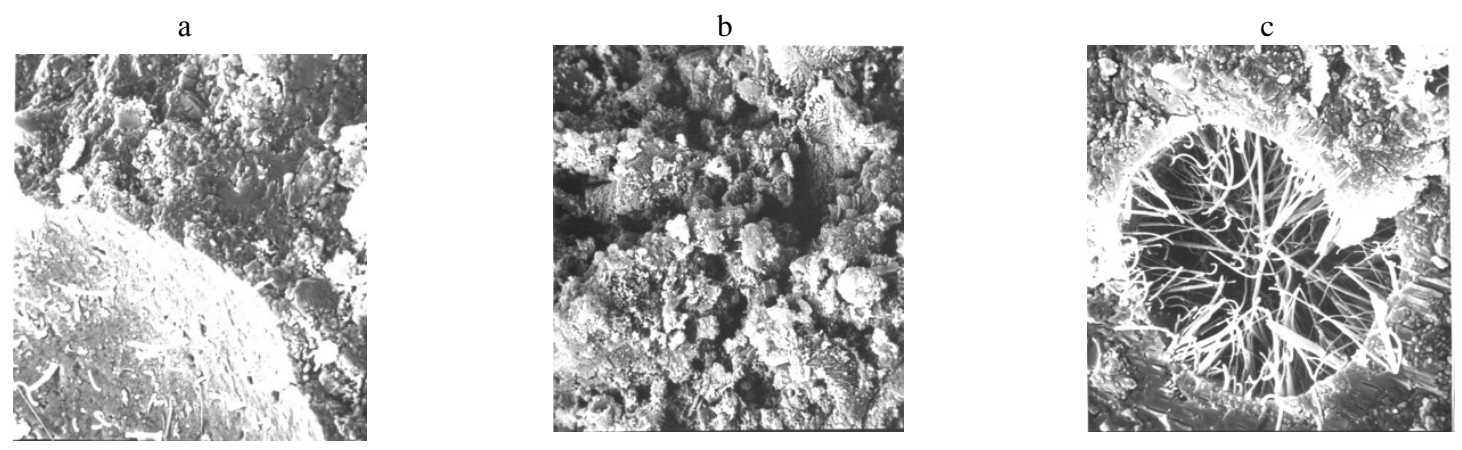

Fig. 3. Stereo images of the fracture of the cement-sand samples surface (500 times magnification)
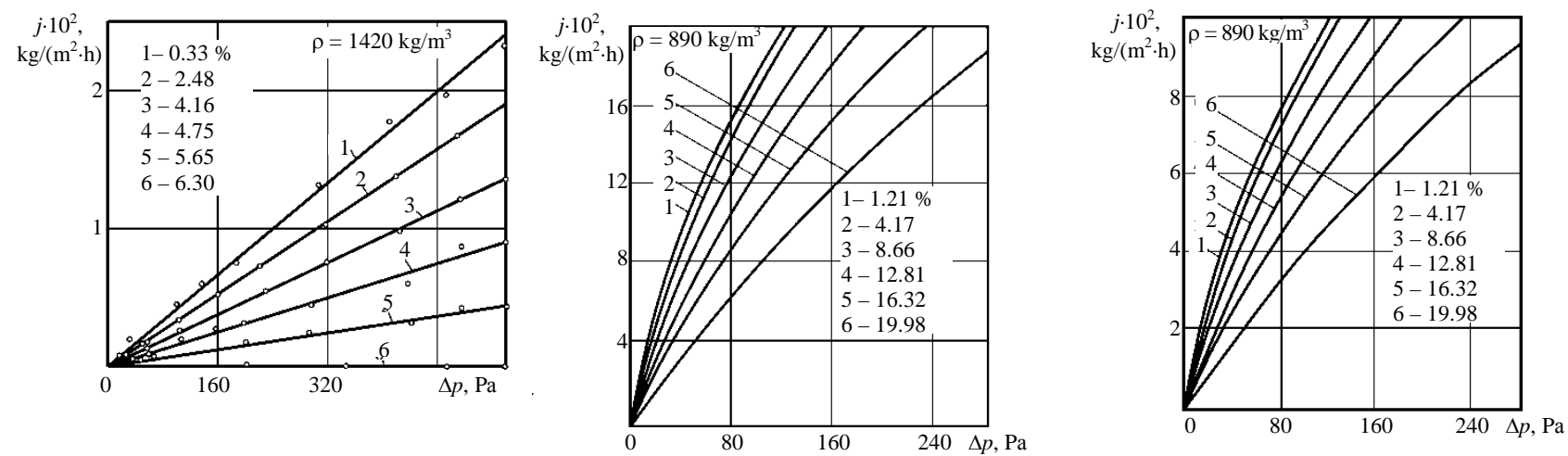

Fig. 4. Dependences of filtration flows on pressure drops at different moisture content and density of materials

\section{Stable equilibrium of road surface}

A state of relatively stable equilibrium (metastable) is a state when the road surface keeps in for a long time, and slight deviation in road thermophysical parameters do not lead to local changes. The task is to determine an equilibrium state for each directed real and spontaneous process. A road pavement is a system that does not exchange heat and work with the ambient environment, therefore, the internal energy and specific volume are constant for it; the entropy tends to a maximum, i. e. $d S=0$ for reversible processes, and $d S \geq 0$ should be assumed for irreversible processes.

The isobaric-isothermal potential decreases in a metastable region reaching a maximum in an equilibrium state and the only type of pavement work in the process of interaction with the ambient environment is expansion. The internal energy, entropy, free energy, isobaric-isothermal potential characterizing the conditions of thermodynamic road equilibrium with the ambient environment are the main equilibrium functions with the characteristic property $[4,13,14]$ :
- if the characteristic function represented by corresponding function for each variable is known then any thermodynamic quantity can be calculated;

- if the internal energy is presented as a function of the specific volume and entropy then the other thermodynamic parameters are determined from the formulas: $p=\left(\frac{u}{v}\right)_{s}, T=\left(\frac{\partial u}{\partial S}\right) v$.

The entropy, free energy, isobaric-isothermal potential, etc. are calculated with the known $u, v, S$, $p, T$. If the enthalpy $h$ is known as pressure function, entropy function then: $T=\left(\frac{\partial h}{\partial S}\right)_{p}, v=\left(\frac{\partial h}{\partial p}\right)_{s}$.

The internal energy, dependences of free energy on the volume $V$ and temperature $T$ are calculated with the known $h, p, S, T$ from the formulas: $p=-\left(\frac{\partial h}{\partial V}\right)_{T}, S=-\left(\frac{\partial h}{\partial h}\right)_{v}$.

$I, u, h, \Phi$ are determined with the known $F, V$, $T, p, S, h$ : 


$$
V=-\left(\frac{\delta \Phi}{\delta \rho}\right)_{T} ; S=-\left(\frac{\delta \Phi}{\delta T}\right)_{\rho} .
$$

If we know the dependence of isobaric-isothermal potential $\Phi$ on pressure $p$, temperature $T$ it is possible to calculate the internal energy and other quantities. From the equilibrium condition for an isolated single-phase system, the temperature and pressure are the same. In a two-phase system, the general condition for phase equilibrium is that substances and their masses pass from one phase to another.

For a system with $V_{\text {syst }}=$ const, $m_{\text {syst }}=$ const, $u=$ const:

$$
V=V_{1}+V_{2} ; m_{\text {syst }}=m_{1}+m_{2},
$$

where 1, 2 - indices corresponding to the first and second phases.

In contrast to a one-dimensionally isolated system, in addition to the known $V$ and $u$, the substance masses in each of the subsystems are known:

$$
\begin{gathered}
m=m_{1}+m_{2} ; u=u_{1}+u_{2} ; \\
d V_{1}=-d V_{2} ; d m_{1}=-d m_{2} ; \\
d u_{1}=-d u_{2} ; d S_{0}=0 ; S_{0}=S_{1}+S_{2} .
\end{gathered}
$$

Consequently

$$
d S_{\text {syst }}=d S_{1}+d S_{2}=0 .
$$

Let us consider the expression for the total differential entropy of the subsystem (1). Obviously, the entropy of the subsystem $S_{1}$ should be regarded as a function of the volume $V_{1}$, mass, i. e. $S_{1}=f\left(V_{1}, u_{1}, m_{1}\right)$. Accordingly:

$$
\begin{gathered}
d S_{1}=\left(\frac{\partial S_{1}}{\partial u_{1}}\right)_{v_{1} m_{1}} ; d u_{1}+\left(\frac{\partial S_{1}}{\partial V_{1}}\right)_{u_{1} m_{1}} ; \\
d V_{1}+\left(\frac{\partial S_{1}}{\partial m_{1}}\right)_{u_{1} V_{1}} d m_{1},
\end{gathered}
$$

since:

$$
\left(\frac{\partial S}{\partial u}\right)_{v_{1} m_{1}}=\frac{1}{T} ;\left(\frac{\partial S}{\partial V}\right)_{u m}=\frac{P}{T} ;\left(\frac{\partial S}{\partial m}\right)_{u V}=-\frac{\varphi}{T} .
$$

Therefore, the expressions for the first and second subsystems may be written as:

$$
\begin{aligned}
& d S_{1}=\frac{1}{T_{1}} d u_{1}+\frac{p_{1}}{T_{1}} d V_{1}-\frac{\varphi_{1}}{T_{1}} d m_{1} \\
& d S_{2}=\frac{1}{T_{2}} d u_{2}+\frac{p_{2}}{T_{2}} d V_{2}-\frac{\varphi_{2}}{T_{2}} d m_{2}
\end{aligned}
$$

Thereat [1]

$$
\begin{gathered}
\left(\frac{1}{T_{1}}-\frac{1}{T_{2}}\right) d u_{1}+\left(\frac{p_{1}}{T_{1}}-\frac{p_{2}}{T_{2}}\right) d V_{1}- \\
-\left(\frac{\varphi_{1}}{T_{1}}-\frac{\varphi_{2}}{T_{2}}\right) d m_{1}=0 .
\end{gathered}
$$

For the equality of the left side of the equation, the factors at the differentials must be equal to zero [2]:

$$
\frac{1}{T_{1}}-\frac{1}{T_{2}}=0 ; \quad \frac{p_{1}}{T_{1}}-\frac{p_{2}}{T_{2}}=0 ; \quad \frac{\varphi_{1}}{T_{1}}-\frac{\varphi_{2}}{T_{2}}=0 .
$$

Therefore, if the phases are in equilibrium their temperatures, pressures, chemical potentials are equal to each other as in a system with the number of existing phases more than two.

\section{CONCLUSIONS}

1. Processing of analytical and experimental engineering calculations of thermal stability of traditional highway pavement suggests to consider them as semi-limited bodies with cyclical temperature fluctuations in atmospheric air, heat transfer coefficients, convective heat exchange in an unlimited space with natural, forced convection, radiation - between the atmosphere, surfaces of roadside construction objects, forest plantations, vehicles. Nonstationary heat transfer occurs at the temperature fields, their gradients, and mass ratios correspondence to boundary conditions of the $1^{\text {st }}$ to $4^{\text {th }}$ types.

2. Research, computational analysis of physical, technical, heat and mass transfer processes in road pavement, their coverings, boundary thermal and dynamic layers show the importance of studying such indicators as a coefficient of linear thermal expansion, thermal diffusivity, heat assi- 
milation of mixture components, etc. upon which strength, reliability and durability of road pavement including road covering and roadbed depend on.

The research has been carried out in accordance with the National key R\&D Program of China (SQ2018YFE010143) and the implementation of the Henan innovation demonstration project (191110211500) with the support of the Henan Center for Outstanding Overseas Scientists, Grant Number G $\mathrm{T}$ ZS 2018006 (People's Republic of China, Henan Province).

\section{REFERENCES}

1. Akelyev V. D. (2010) Heat and Mass Transfer in Confined Spaces of Building Structures and Structures. Minsk, Belarussian National Technical University. 317 (in Russian).

2. Pshembayev M. K. (2017) Physical and Chemical Fundamentals of Protection Processes for Surface Layer of Concrete Road Paving by Impregnating Compositions. Nauka i Tekhnika = Science \& Technique, 16 (2), 144-152. https:/doi. org/10.21122/2227-1031-2017-16-2-144-152 (in Russian).

3. Pshembayev M. K., Kovalev Ya. N., Shevchuk L. I. (2017) Analysis of Stress State in Upper Layer of Road Concrete Pavement with Temperature Action. Nauka i Tekhnika = Science \& Technique, 16 (4), 282-288. https://doi.org/10. 21122/2227-1031-2017-16-4-282-288 (in Russian).

4. Akelyev V. D. (2013) Heat and Mass Transfer in Confined Spaces of Building Structures. Minsk. 45 (in Russian).

5. Misnar A. (1968) Thermal Conductivity of Solids, Liquids, Gases and their Compositions. Moscow, Mir Publ. 464 (in Russian).

6. Tingguo Liu, Zankavich V. N., Aliakseyeu Yu. H., Khroustalev B. M. (2019) Recycling of Materials for PavementDressing: Analytical Review. Nauka i Tekhnika = Science \& Technique, 18 (2), 104-112. https://doi.org/10.21122/22271031-2019-18-2-104-112.

7. Khroustalev B. M., Tingguo Liu, Akeliev V. D., Zhongyu Li, Aliakseyeu Yu. H., Zankavich V. V. (2019) Heat Resistance and Heat-and-Mass Transfer in Road Pavements. Energetika. Izvestiya Vysshikh Uchebnykh Zavedenii i Energeticheskikh
Ob'edinenii SNG = Energetika. Proceedings of CIS Higher Education Institutions and Power Engineering Associations, 62 (6), 536-546. https://doi.org/10.21122/1029-2019-62-6536-546.

8. Khroustalev B. M., Veranko V. A., Zankavich V. V., Aliakseyeu Yu. G., Xuejun Yu., Shang B., Shi J. (2020) Structure Formation and Properties of Concrete Based on Organic Hydraulic Binders. Nauka i Tekhnika = Science and Technique, 19 (3), 181-194. https://doi.org/10.21122/2227-10312020-19-3-181-194.

9. Khroustalev B., Liu T., Busel A., Li Zh., Veranko U., Zankavich V., Shang B. (2020) Estimation and Methods of Prediction the Structural and Mechanical Properties of RAPComposites. Izvestiya NAN Respubliki Kazakhstan. Seriya Geologii i Tekhnicheskikh Nauk = News of National Academy of Sciences of the Republic of Kazakhstan. Geology Series and Technical Sciences, (2), 187-197 (in Russian).

10. Khroustalev B. M., Leonovich S. N., Potapov V. V., Grushevskaya E. N. (2017) Composite Material Based on Cement Binders Modified with $\mathrm{SiO}_{2}$ Nanoadditives. Nauka i Tekhni$k a$ = Science \& Technique, 16 (6), 459-465. https://doi.org/ 10.21122/2227-1031-2017-16-6-459-465.

11. Dulnev G. N., Zarichnyak Yu. P. (1974) Thermalconductivity of Mixtures and Composite Materials. Leningrad, Energiya Publ. 264 (in Russian).

12. Zhdanok S. A., Polonina E. N., Leonovich S. N., Khroustalev B. M., Koleda E. A. (2018) Increasing Strength of Concrete with Plasticizing Additive Based on Nanostructured Carbon. Stroitelnye Materialy = Construction Materials, (6), 67-72 (in Russian).

13. Khroustalev B. M., Akeliev V. D., Aliakseyeu Yu. H., Shi Jicun, Zankovich V. V., Liu Tingguo (2018) Specific Features of Heat and Mass Transfer Processes in Road Dressings. Energetika. Izvestiya Vysshikh Uchebnykh Zavedenii i Energeticheskikh Ob'edinenii SNG = Energetika. Proceedings of CIS Higher Education Institutions and Power Engineering Associations, 61 (6), 517-526. https://doi.org/10.21122/10297448-2018-61-6-517-526.

14. Kammerer I. S. (1965) Thermal Insulation in Industry and Construction. Moscow, Stroyizdat Publ. 378 (in Russian).

Received: 29.09.2021

Accepted: 30.11 .2021

Published online: 28.01.2022 